\title{
EFFECTS OF INUNDATION DEPTH ON GROWTH OF 14 PLANT SPECIES ON PEATLANDS IN PULANG PISAU REGENCY
}

\author{
Johanna M.Rotinsulu, Lies Indrayanti, Sampang \\ Forestry Department, Agricultural Faculty \\ Palangka Raya University, Palangka Raya, Central Kalimantan \\ Email: hannangga@gmail.com
}

\begin{abstract}
Rehabilitation of degraded peat-swamp forests, especially in Central Kalimantan Province, is becoming increasingly important in order to restore the ecological functions and maintain the biodiversity and carbon pool. The problem facing the rehabilitation effort is the limited knowledge about the techniques of rehabilitation on peat swamp lands using local species because inundation frequently occurs in this area during rainy season which greatly affects the growth of the plants. The purpose of this study was to analyze the level of resistance of plants to inundation on peat swamp lands in Pulang Pisau Regency, Central Kalimantan Province. The experiment was conducted in Taruna Jaya village, Jabiren subdistrict. Pulang Pisau Regency, using 14 different plant species endemic to peat swamp forests, with two factors, namely the level of immersion/inundation and plant species. In order to find out the plant resistance to inundation and the root growth, some variables were measured, such as the survival percentage of plants after tested in inundation and planted in the field, the assessment of the tree health using the criteria of Forest Health Monitoring (FHM), and the root-shoot ratio (RSR). The results showed that of the 14 species tested, Belangeran (Shorea balangera Korth) and Bintangur (Calophylum sp.) had good resistance to the condition of inundated soil, high adaptability in the field, and high value of RSR (root- shoot ratio). The plant species with high efficiency in absorbing nutrients and water were Shorea balangeran Korth, Calophyllum sp., Dyera polyphylla, and Alstonia pneumatophora. Those with the very high value of tree health were Alstonia pneumatophora, Calophyllum sp., $D$. pseudomalabarica, Dyera polyphylla, Shorea balangeran Korth, Trisraniopsis sp. and Stemonurus secondflorus.
\end{abstract}

Keywords: inundation, peat swamp, plant species, rehabilitation

\section{INTRODUCTION}

Peat swamp forests have a diversity of plants relatively low compared with the vegetation type of other lowland forests in the tropics. The diversity of plant species in peat swamp forests is equivalent to a diversity of plants in kerangas forests and sub-mountain forests, but still higher than the biodiversity in mountain forests and mangroves (Simbolon \& Mirmanto, 2000; Wibisono et al., 2005). Various species of trees often found on peatlands are Dyera lowii, Gonystylus bancanus, Combretocarpus rotundatus, Cococerass boornense, Alstonia pneumatophora, Barringtonia racemosa, Campnosperma macrophylla, Palaquium rostratum, Calophyllum sclerophyllum, Shorea balangera Korth, and Melanorrhoea walichii. In addition to trees, peat swamp forests also have the variety of palm species, such as Salacca converta, Cyrtoctachys lakka, Licuala paludosa, Pholidocarpus sumatranus, Calamus spp., Khortalsia spp., and Caryota mitis.

Rehabilitation of degraded peat-swamp forests, especially in the province of Central Kalimantan, is becoming increasingly important in order to restore ecological functions of the area and maintain the biodiversity and carbon pool. One of the obstacles in the rehabilitation effort is the limited knowledge about techniques of rehabilitation on peatland using local species (Rieley \& Ahmad Shah, 1996; Page et al., 2009), because inundation frequently occurs in this area during rainy season which greatly affects the growth of the plants (Giesen, 2004; Wösten et al, 2008; Page et al, 2009).

This phenomenon was exacerbated by the destruction of peatlands which occur almost every year. As a result of this damage, the increased risk has been established in the form of deeper and longer inundation in the area of rehabilitation on peatlands (Wösten et al, 2008) which can lead to death of the plants, especially during rainy season.

Natural distribution of trees in permanently or periodically submerged 
condition provides an important indicator for the selection of local tree species that can adapt to the ecological nature that is tolerant to submerged condition (Justin \& Armstrong, 1987; Bolm, 1999; Glenz et al, 2006). However, the levels of sensitivity and adaptability of tree species in the peat-swamp forest ecosystem when submerged is still not well understood. Some plants prefer stagnant conditions while others like otherwise (William, 1987; Jackson \& Armstrong, 1999; Colmer \& Greenway 2005). For plants that do not fit in the submerged areas, stagnant water can cause root rot and lack of oxygen in the rhizosphere and therefore affects the plant growth (Kozlowski, 1984). Therefore, study on the resistance/adaptation of particular plant species on peat swamps in Pulang Pisau Regency of Central Kalimantan Province is indispensable in the attempt to rehabilitate the fire-affected areas.

\section{MATERIALS AND METHODS}

This study was conducted in the village of Tanjung Taruna Jaya located at coordinates $\left(02^{\circ} 17^{\prime} 19^{\prime \prime} \mathrm{S}\right.$ and $114^{\circ} 01^{\prime} 57^{\prime \prime}$ E), Jabiren sub-district, Pulang Pisau regency, for 10 (ten) months.
The equipment used in the study was location map; camera; computer; wooden box; GPS; and stationery. The materials needed were 14 (fourteen) species of plants with an average height of $36-40 \mathrm{~cm}$.

The study consisted of 42 treatment combinations from factors of levels of immersion/inundation (L1, L2 and L3) and the plant species, namely Pulai (Alstonia pneumatophora/J1); Belangeran (Shorea balangera Korth/J2); Rasak (Cotylelobium lanceolatum/J3); yellow Meranti (Shorea spp./ J4); Meranti bako (Shorea uliginosa/J5); Bintangur (Calophyllum sp./J6); Pisangpisang (Stemonurus secondflorus/J7); Jelutung (Dyera polypylla/J8); Keruing (Dipterocarpus sp./J9); Hangkang (Palaquium sp./J10); Kapur Naga (Palaquium sclerophllum/J11); Belawan (Tristaniopsis sp./J12); Uringpahe (Diospyrus pseudomalabarica/J13); and Bintangur (Calophyllum sp./J14). Each treatment consisted of 20 plants as the samples, so it needed 840 plants $(42 \times 20$ plants $=840)$. The illustration of the immersion/inaudation treatment for each plant species is shown in Figure 1.

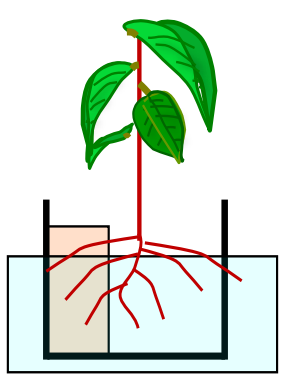

$\mathrm{L}_{1}$

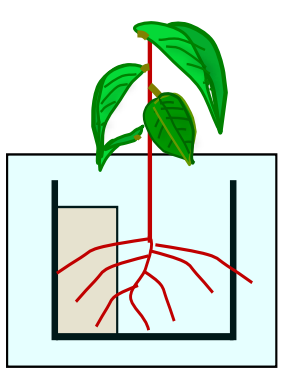

$\mathrm{L}_{2}$

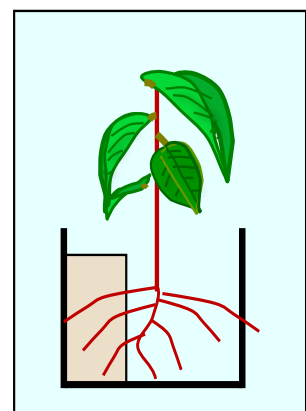

$\mathrm{L}_{3}$

Figure 1 Three levels of immersion / inundation, namely L1 (low immersion/inundation $=20 \mathrm{~cm}$ ), L2 $($ moderate immersion/inundation $=40 \mathrm{~cm})$ and $\mathrm{L} 3($ total immersion/inundation $=60 \mathrm{~cm})$.

The assessment of tree health was carried out using the criteria of Forest Health Monitoring (FHM).

The assessment was in a scale of 0 to 3.44; where a healthy (flawless) tree had a value of 3.44 and a dead tree had a value of 0 . The calculation of the defective trees $(\mathrm{Vd})$ as follows (Kasno \& Wahyudi, 2009):

$$
\mathrm{Vd}=\sum_{\mathrm{i}=1}^{\mathrm{n}}[(1-\log \mathrm{Ld}) \mathrm{x} \mathrm{Pd}]
$$

Where :

$$
\text { Ld : flaw location (Figure 4) }
$$

Pd : percentage of the flawed part

$\mathrm{n}: 1$ to 9

To compare the two data, the Chi Square test (Sudjana, 1992) was used as follows:

Where :

$$
\rho^{2}=\sum_{i=1}^{n} \frac{\left(O_{i}-E_{i}\right)^{2}}{E_{i}}
$$

$\mathrm{O}_{\mathrm{i}} \quad$ : actual data (observed) at $-\mathrm{i}$

$\mathrm{E}_{\mathrm{i}} \quad$ : expected data/modeling result (expected) at $-\mathrm{i}$ 
$\mathrm{n} \quad$ : number of data sets

When the value of $X^{2}$ count $\geq X^{2}$ tabel (db-1; 0.05), the data is $\mathrm{H}_{1}$ (different data)

When the value of $X^{2}$ count $<X^{2}$ tabel (db-1; 0.05), the data is $\mathrm{H}_{0}$ (homogenous data)

Meanwhile the level of data accuracy was calculated on the basis of mean absolute percentage error (MAPE) with equation (Wahyudi, 2011):

$$
y=100 \%-\left[1 / \mathrm{n} \sum_{\mathrm{i}=1}^{\mathrm{n}} \frac{\left|\mathrm{O}_{\mathrm{i}}-\mathrm{E}_{\mathrm{i}}\right|}{\mathrm{E}_{\mathrm{i}}} \times 100 \%\right]
$$

Criteria: $y>80 \%=$ Very Accurate

$y=75 \%-79.99 \%=$ Accurate

$y=60 \%-74.99 \%=$ Fairly Accurate

$\mathrm{y}<60 \%=$ Not Accurate

Root-shoot ratio (RSR) and the root system
Those values are expressed in grams. Root-shoot ratio (RSR) was calculated by this formula (Watson, 1947 in Sitompul and Guritno, 1995):

$$
\mathrm{NPA}=\frac{\mathrm{W}}{\mathrm{WA}}
$$

Where:

W : Biomassa of total plants

WA : Root weight ratio

\section{RESULTS AND DISCUSSION}

\section{Survival Percentage of plants}

Survival percentage of plants toward the test of immersion/inundation of water was obtained from the data of 14 plant species toward the test of immersion/inundation for 1 (one) month as presented in Figure 2.

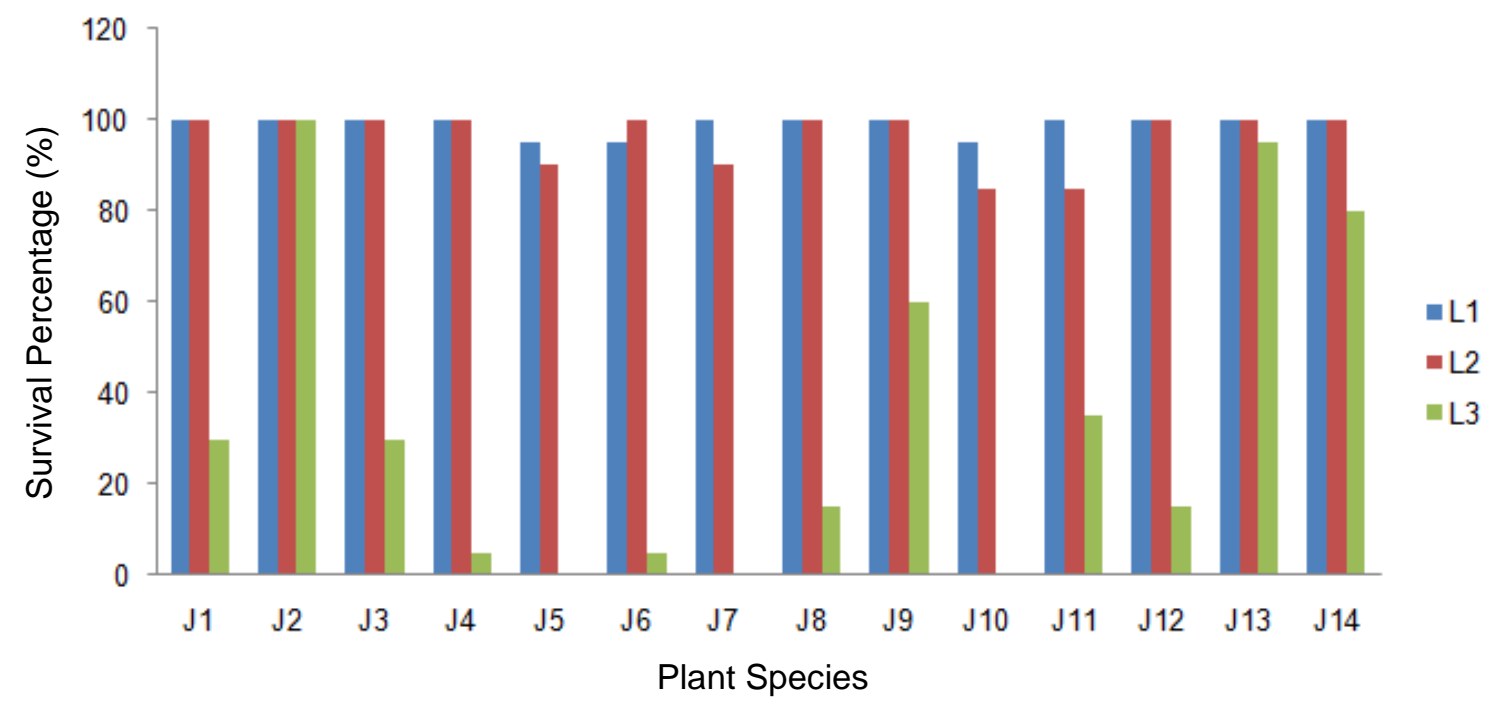

Figure 2 Survival percentages of plants in immersion test

The results of immersion/inundation test on the species of plants in treatments $L_{1}$, $L_{2}$ and $L_{3}$ for 1 (one) month showed that balangeran could survive, with the survival percentage for each in each treatment was $100 \%$, followed by Uringpahe in treatment $L_{3}$ with the survival percentage of $95 \%$. While other species of plants could only survive in the treatments of $L_{1}$ and $L_{2}$, and then their survival percentage declined in treatment $L_{3}$. Even some plant species such as Meranti poka, Pisang-pisang and Hangkang could not survive in treatment $L_{3}$. The inundation limited the growth because of the root rot resulting in the lack of oxygen in the root rhizosphere (Kozlowski, 1984).
Peat swamp plants can avoid a shortage of $\mathrm{O}_{2}$ in the roots by transporting $\mathrm{O}_{2}$ from air to the submerged roots in water through the parenchymal tissue. In submerged condition, lack of light entering through a very limited vertical immersion, water was also a serious factor limiting the process of photosynthesis (Blom \& Voesenek, 1996). The study of the level and duration of immersion will be used to rehabilitate the former PLG land optimally, namely by identifying the condition of the land prior to planting. Balangeran, Uringpahe and Bintangur can be planted in the areas severely damaged and inundated by water while Pulai, Jelutung, Hangkang, Kapurnaga, Bintangur, 
Rasak, Pisang-pisang, Meranti and Belawan can be grown on land with minor to medium damages.

\section{Survival Percentage in Field}

In general, the average $\mathrm{pH}$, rainfall, and air temperature at the planting sites for the 14 (fourteen) plant species were 3.56, 4,656 mm per year, and $25.0^{\circ} \mathrm{C}$, respectively, UNPAR Cimtrop Team report (2013). Based on the observations in the field for three months, shown in Figure 3, the species with the highest survival percentage when planted in open field (> 90\%) were S. balangeran Korth (J2) followed by Calophyllum sp. (J6), Alstonia pneumatophora (J1), and Stemonurus secondflorus (J7). The plants with the survival percentage less than $90 \%(<90 \%)$ were Dipterocarpus sp. (J9), Cotylelobium lanceolatum (J6), Dyera polypyllaShorea spp (J8), Shorea uloginosa (J4), Diospyrus pseudomalabarica (J11), Calophyllum sp. (J14), and Palaquium sp. (J10) while the species with the lowest survival percentage (below 60\%) was Palaquium sclerophllum (J11).

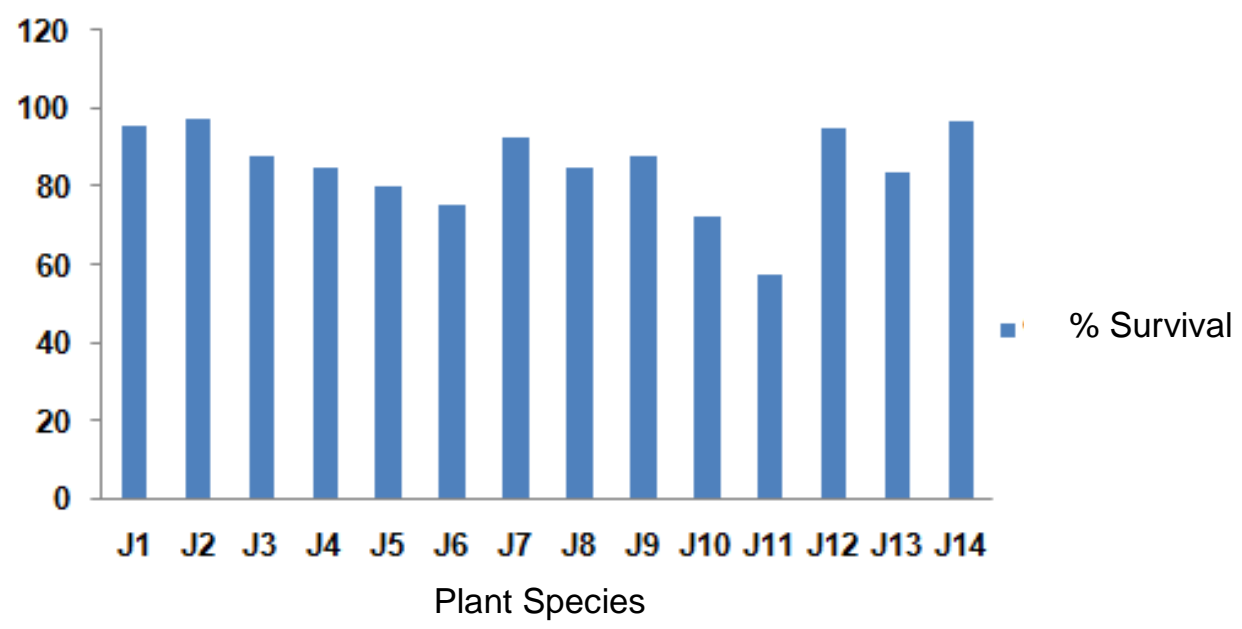

Figure 3 Survival Percentages of Plant Species in Field

Balangeran (J2), Uringpahe (J13) and Bintangur (J6) had the adaptability to the environment and as a peat swamp plant recommended for the rehabilitating plant species, especially in inland peatlands, followed by Pulai, Jelutung, Bintangur, Kapurnaga, Pisang-pisang, Rasak, Yellow meranti, Meranti pako, Hangkang, Uringpahe, Keruing and Belawan. With their good adaptability to inaudation and high survival percentage, these species can be used as superior plants in land rehabilitation by providing silvicultural treatments which are good, intensive and in accordance with the conditions of the lands.

The results of the study conducted by Usis (2009) showed that Balangeran, Pulai,
Galam and Jelutung had the survival percentage of $>50 \%$, and Balangeran topped the list, followed by Pulai, Galam and Jelutung. If associated with durability, strength and utilization the wood of Balangeran, Uringpahe and Belawan had high economic value, followed by Bintangur, Kapurnaga, Keruing, Meranti, Rasak, Pisang-pisang and Hangkang which are recommended for rehabilitation of degraded land. The selection of species for land rehabilitation was based on not only the site condition but also the economic value. Belangeran's resistance and adaptability to inaudation in the environment of planting site is shown in Figure 4. 

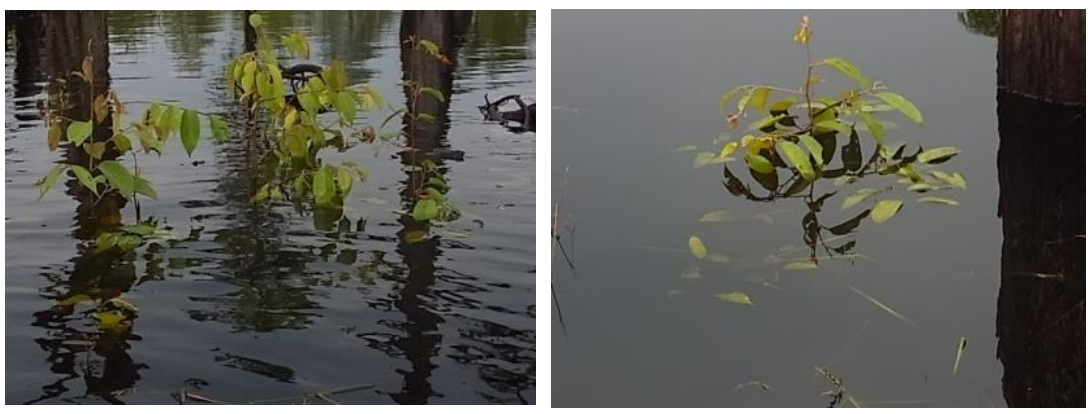

Figure 4 Growth of Balangeran and its tolerance to moderate and total inaudation

\section{Health Level of Tiller/Tree}

The results of FHM analysis (Table 8) on Pulai, Bintangur, Uringpahe, Belawan, Jelutung, Balangeran, and Pisang-pisang showed that it had a mean absolute percentage error (MAPE) of $99.99 \%$ for each species. Thus, the model was still feasible to be used because it had a fairly high accuracy.

Table 1 Data of FHM observation on seven species in field

\begin{tabular}{llccc}
\hline \multicolumn{1}{c}{ Species / Local Name } & \multicolumn{1}{c}{ Scientific Name } & $\begin{array}{c}\text { Number of } \\
\text { Samples }\end{array}$ & Chi Kuadrat $\left(\mathrm{X}^{2}\right)$ & $\begin{array}{c}\text { T-table } \\
\mathrm{X}^{2}\end{array}$ \\
\hline Pulai & Alstonia pneumatophora & 10 & 0.0406 & 3.33 \\
Jelutung & Dyera polypylla & 20 & 0.0314 & 10.12 \\
Bintangur & Calophyllum sp. & 20 & 0.0729 & 10.12 \\
Uringpahe & D. pseudomalabarica & 20 & 0.1784 & 10.12 \\
Pisang-pisang & Stemonurus secondflorus & 20 & 0.0637 & 10.12 \\
Balangeran & Shorea balangera Korth & 20 & 0.0540 & 10.12 \\
Belawan & Tristaniopsis sp. & 20 & 0.1019 & 10.12 \\
\hline
\end{tabular}

Model evaluation was performed on seven (7) species of peat swamp plants using Chi-Square against some species such as Pulai producing the value of $X^{2}$ count at 0.0406 which was smaller than the value of $X^{2}$ table 0.95 at 3.33 , followed by other species, so it can be said that the resulting model were reliable (useable). To determine the accuracy of the resulting model, an evaluation of the model was carried out by comparing the results of measurements of plant species in the nursery (expected) and the data of stands from the direct measurements of the field (observed). The observation and measurement of peat swamp plant species as the compositions of the forest stands (observed) were performed at the Natural Laboratory of Peat Swamp Forest (NLPSF) in Sabangau. Trees with damages or defects caused by nature (not the damages caused by humans) were determined by the danger levels of the damages to the growth and survival of the trees. The FHM observations in the field are shown in Figures 5. 

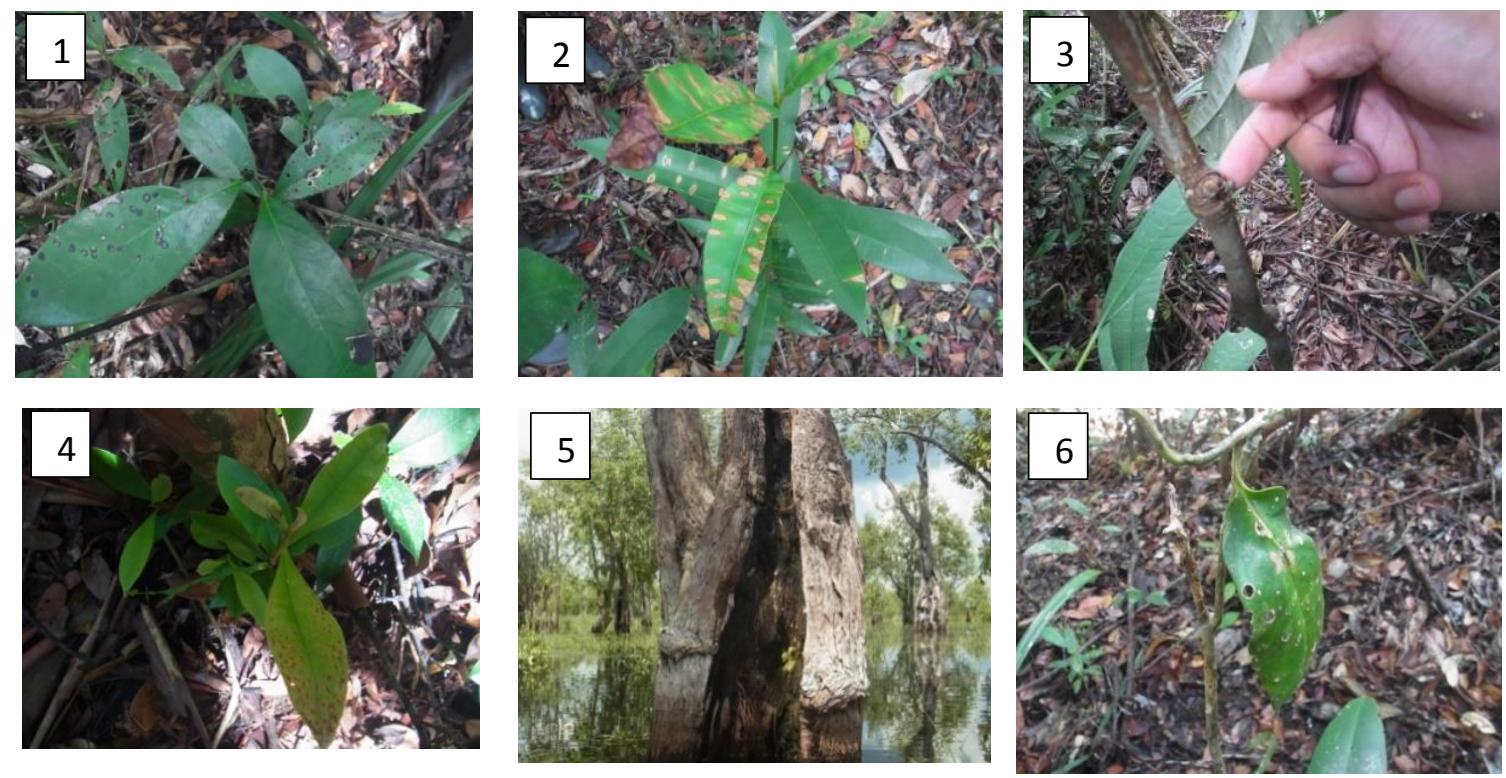

Figure 5 The FHM observations in the field are D.pseudomalabarica (1), Calophyllum sp. (2), Dyera polypylla (3), Tristaniopsis sp. (4), Shorea balangeran (5), and Stemonurus secondflorus (6)

Peat swamp forests in Sabangau has a diversity of plant species relatively lower compared with the forest vegetation in the other lowland tropical areas. One of the main causes of the tropical forest destruction in Indonesia is fire. After a fire, the vegetation on the peat surface disappears and peat soil layer is reduced and form a basin, and in rainy season it will be inundated, creating a pool resembling a lake. This puddle is the media for spreading the seeds because the vegetation appears after fire. However, only a few certain plant species are able to survive the severe inundation, such as Perepat (Combretocarpus rotondatus), Pulai (Alstonia pneumatophora), balangeran (Shorea balangeran), and Pandanus spp.

Every form of peat swamp forest destruction will always be followed by a typical response of environment. This response aims at improving the demaged environment in accordance with remaining land potential and several other influential factors, among others, water. Water is the medium that is most responsible for the distribution of seeds of peat swamp plants whose small and lightweight seeds, and when the inaudation subsides, such plant species will grow. Pulai, jelutung, balangeran, and Dipterocarpaceae species are lightweight so that it is very common to find the wilding far from the mother plant. Certain plant species such as tumih/perepat, jelutung, and balangeran has a pretty high restoration/tolerance capability against fires through resprouiting. Based on the experience in the field such species were able to recover through resprouiting, as shown in Figures 6. 

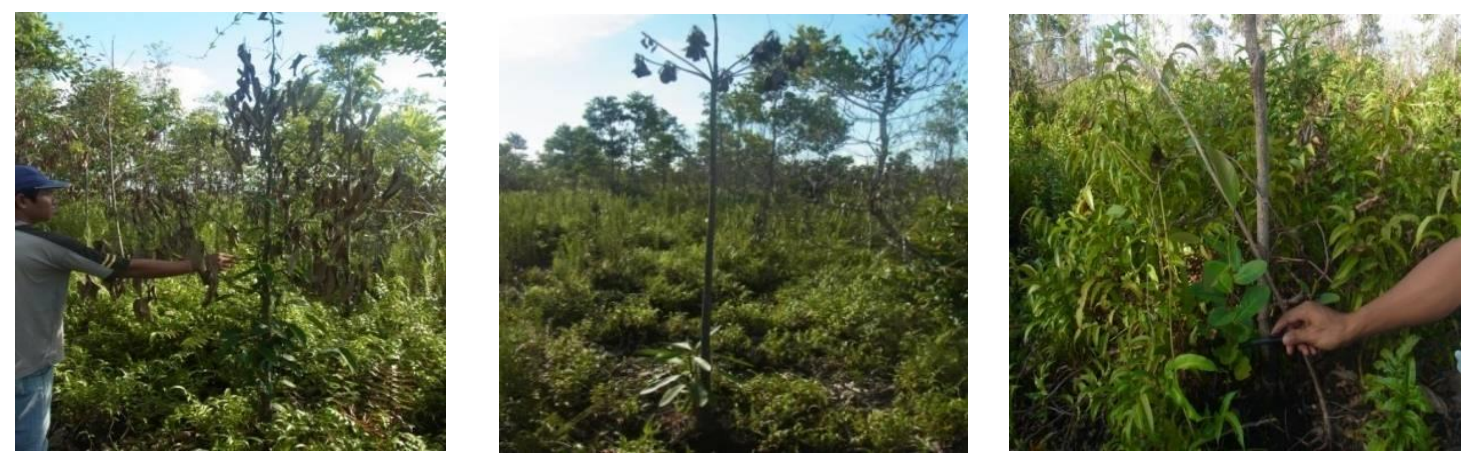

Figure 6 The experience such species were able to recover through resprouiting in the field are (from the left to the right) Shorea balangera, Dyera polypylla and Combretocarpus rotundatus (Miq).

\section{Root-Shoot Ratio (RSR) and Root System}

Information on root-shoot ratio is required to determine the balance between the growth of shoots as the place where the the process of photosynthesis take place, and with the root growth as the field for nutrient and water uptake (Wulandari AS, et al, 2011). The data of the root-shoot ratio of plants are presented in Table 2.

Table 2 Average root-shoot ratio of plants in the end of the study

\begin{tabular}{ccccc}
\hline \multirow{2}{*}{ Sample } & \multicolumn{4}{c}{ Plant Species } \\
\cline { 2 - 4 } & Balangeran & Bintangur & Jelutung & Pulai \\
\hline 1 & 1.6842 & 1.7692 & 1.5000 & 2.3684 \\
2 & 2.4669 & 0.7122 & 1.5882 & 1.1000 \\
3 & 3.6785 & 2.1659 & 0.9355 & 2.5714 \\
4 & 2.1538 & 2.8214 & 2.0667 & 1.4615 \\
Total & 9.9835 & 7.4687 & 6.0904 & 7.5014 \\
Average & 2.4958 & 1.8667 & 1.5226 & 1.8775 \\
\hline
\end{tabular}

The highest RSR was on balangeran (2.4958), pulai (1.8775), bintangur (1.8667) and jelutung (1.5226). The highest RSR on balangeran, pulai and bintangur showed the better root efficiency in absorbing nutrients and water than jelutung. The condition of the planting area is homogenous both in the availability of water and nutrients and in the elements of the environment (temperature and sunlight), so the good root efficiency was to support the formation of plant biomass.

Plants with high root-shoot ratio showed that shoot growth was higher than the growth of roots. However, the roots were quite capable of supporting the growth of shoots. In addition, a high root-shoot ratio was one of the indicators to determine the media was relatively fertile and provided sufficient water. The lower root-shoot ratio had more root formation than the shoot formation that showed the condition of media lack of nutrients so that the root formation was relatively more than the shoot formation, in supporting these plants to increase the absorption resulting in low root-shoot ratio (Frianto 2006). The small value of RSR actually made the plants more resistant when planted in the field because it had strong roots, but the balance between the ability of roots to absorb nutrients and the ability of shoots in doing transpiration and photosynthesis should be kept.

\section{CONCLUSIONS}

Balangeran (Shorea balangeran Korth), Uringpahe (D. Pseudomalabarica) and Bintangur (Calophyllum sp.) are the species that are resistant to inundation. In addition, of 14 species planted in the planting sites, most had the average survival percentage $>60 \%$, except Kapur naga (Palaquium sclerophllum). The plant species that had a high value of RSR and showed high efficiency in absorbing nutrients and water were Shorea balangeran Korth, Calophyllum sp., Dyera polyphylla and Alstonia pneumatophora. Meanwhile, the species with the very high value of tree health were Alstonia pneumatophora, Calophyllum sp., D. Pseudomalabarica, Dyera polyphylla, Shorea balangeran Korth, Trisraniopsis sp., and Stemonurus secondflorus. 


\section{REFERENCES}

Anderson, J.A.R. (1964). The structure and development of the peat swamps of Sarawak and Brunei. J.Tropical Geography 18: 7-16.

Blom, C.W.P.M., and Voesenek, L.A.C.J. (1996). Flooding: the survival strategies of plants. Trends in Ecology \& Evolution 11: 290-295.

BPS (Badan Pusat Statistik) (2013). Pulang Pisau in Numbers 2013. Pulang Pisau Regency.

Department of Forestry (1995). Research Status. Increment and Growth of Industrial Forest Plantations. Forest Research and Development Agency, Forestry Department of Republic of Indonesia, Jakarta.

Direktorat Reboisasi dan Rehabilitasi (1980). Guidelines for Indonesia Selective Logging System. Determination of Silviculture, Implementation and Monitoring Systems. Publication No.A. 56 Year 1980. Jakarta.

Giesen, W. (2004). Causes of peatswamp forest degradation in Berbak National Park and recommendations for restoration. Water for Food and Ecosystems Programme Project on: "Promoting the river basin and ecosystem approach forsustainable management of SE Asian lowland peat swampforests". ARCADISEuroconsult, Arnhem, the Netherlands, pp.125.

Glenz, C., Schlaepfer, R., lorgulescu, I. and Kienast, F. (2006). Flooding tolerance of Central European tree and shrub species. Forest Ecology and Management 235: 1-13.

Istomo (2006). Evaluation and adjustment of silviculture system of peat swamp forests, particularly for ramin species (Gonystylusbancanus (Miq.) Kurz.) in Indonesia. Proccedings. The National Workshop on Alternative Policies in Preservation and Utilization of Ramin. Bogor, 22 February 2006. Center of Forest Research and Development and Natural Conservation in cooperation with ITTOPPD87/03 Rev.2 (F).

Jauhiainen, J., Takahashi, H., Heikkinen, J.E.P., Martikainen, P.J. and Vasander, H. (2005). Carbon fluxes from a tropical peat swamp forest floor. Global Change Biology 11: 1788 - 1797.

Justin, S.H.F.W., and Armstrong, W. (1987). The anatomical characteristics of roots and plant response to soil flooding. New phytol. 106: 465-495.

Kasno, and Wahyudi (2009). Measurement of Forest Health of Gunung Walat, Sukabumi. Graduate Program IPB, Bogor.

Kozlowski, T.T. (1984). Effects of flooding on growth and metabolism of herbaceous plants, In: Kozlowski, T.T. (Ed.), Flooding and plant growth. Physiological Ecology. A series of monographs, Texts, and Treatises. Academic Press. Florida, pp. 129-163.

Martawijaya, A., I.Kartasujana, K.Kadir, and S.A. Prawira (1981). Indonesian Wood Atlas. Volume I. pp. 20-24

(1989). Indonesian Wood Atlas. Volume I. pp. 20-24

Martawijaya (2004). Indonesian Wood Atlas.

Page, S.E, Rieley, J.O and Wust, R. (2006). Lowland Tropical Peatlands of Southeast Asia. In Peatlands Evolution and Records of Environmental and Climate Change. Editor: J.F. Shroder Jr. Elsevier.UK.

Page, S., Hoscilo, A., Wosten, H., Jauhiainen, J., Silvius, M., Rieley, J., Ritzema, H., Tansey, K., Graham, L., Vasander, H. and Limin, S. (2009). Restration ecology of lowland tropical peatlands in Southeast Asia: Current knowledge and future research directions. Ecosystems 12 : 888-905.

Rieley, J.O., and Ahmad-Shah, A.A. (1996). The vegetation of tropical peat swamp forests. In: Maltby, E., Immirzi, C.P., and Safford, R.J. (Eds.), Tropical lowland peatlands of Southeast Asia. Proceedings of a Workshop on Integrated Planning and Management of Tropical Lowland Peatlands, IUCN Wetlands Programme/IUCN The World Conservation Union. Gland, Switzerland, pp. 55-73.

Soerianegara, I dan Indrawan, A. (1978). Indonesian Forest Ecology. Cooperation Agency of Forestry Faculty. IPB. Bogor.

Stuckle I.C., Siregar, C.A., Supriyanto and Kartana, J. (2001). Forest Health 
Monitoring tp Monitor the Sustainability Tropical Rain Forest. ITTO and SeameoBiotrop.

Sudjana (1992). Statistical Methods. Tarsito. Bandung.

Takahashi K, Shybuya, M., Tamai, Y., Saito, H., Istomo, Limin, S.H., Segah, H. and Erosa, P, (2001). Rehabilitation of intensively disturbed sites in peat swamp forest area in Central Kalimantan In Osaki, M., Wijaya, H. and Limin, S.H. (project leaders). Rehabilitation of peatlands and establishment of sustainable agrosystem in Central Kalimantan LIPIJSPS Core University Program, Environmental Conservation and Land Use Management of Wetland Ecosystems in Southeast Asia.

Wahyudi (2011). Identification of Extreme Rainfall in Ngawi Regency Using Generalized Extreme Value and Generalized Pareto Distribution. ITS Press. Surabaya.

Whitmore, T.C., Tantra, I.G.M. and Sutisna, U. (1989). Check List For Sulawesi. Tree Flora of Indonesia. Forest Research and Development Centre. Bogor.

Wibisono, Iwan, T.C., Siboro, L. dan Suryadiputra, I.N.N. (2005). Guidelines for Rehabilitation and Silviculture Techniques in Peat Lands. Climate Change Project, Forest and Peatlands in Indonesia. Wetlands International-Indonesia Programme and Wildlife Habitat Canada. Bogor.

William, L.L. (1987). Flood-Tolerant Trees. Journal of Forestry 85: 36-40.

Wösten, J.H.M., Clymans, E., Page, S.E., Rieley, J.O. and Limin, S.H. (2008). Peat-water interrelationships in a tropical peatland ecosystem in Southeast Asia. CATENA 73 : 212224. 